\title{
Preparation and properties of $\alpha$-tricalcium phosphate microspheres by spray drying
}

\section{(Preparação e caracterização de microesferas de $\alpha$-fosfato tricálcico obtidas por spray drying)}

\author{
C.O.Renó ${ }^{1}$, R. G. Carrodeguas ${ }^{2}$, M.Motisuke ${ }^{1 *}$, M.A. Rodríguez $z^{3}$ \\ ${ }^{I}$ Universidade Federal de São Paulo, Science and Technology Institute, Bioceramics Laboratory, \\ R. Talim 330, 12231-280, São José dos Campos, SP, Brazil \\ ${ }^{2}$ Noricum s.l., Madrid, Spain \\ ${ }^{3}$ Instituto de Cerámica y Vidrio (ICV-CSIC), Kelsen 5, 28049 Madrid, Spain
}

\begin{abstract}
$\alpha$-TCP microspheres were obtained by atomizing aqueous slurries containing $50 \mathrm{wt} \%$ of low crystallinity $\alpha$-TCP and $1 \mathrm{wt} \%$ of citric acid. Poly(ethylene glycol) and poly(vinyl alcohol) were tested as a binder. The spray drying process yielded to microspheres with mean diameter around $20 \mu \mathrm{m}$ and sphericity (horizontal and vertical length ratio) closest to one, which is essential to many applications, such as drug delivery and injectability of cements. The addition of binders was necessary to decrease the amount of loose particles and to improve powder flowability but it also caused a reduction in wettability and surface area. Best results were achieved with $3 \mathrm{wt} \%$ of PVA, as the microspheres presented the highest specific surface area, wettability, and sphericity. The microspheres prepared in this study may be used as injectable bone cements precursor since their geometry and flowability would favor paste homogeneity and injectability overcoming many drawbacks of today's injectable bone cements.

Keywords: microspheres, spray drying, $\alpha$-tricalcium phosphate.
\end{abstract}

\section{Resumo}

Microesferas de $\alpha$-TCP foram obtidas atomizando uma suspensão aquosa contendo $50 \%$ em massa de $\alpha$-TCP com baixa cristalinidade e $1 \%$ em massa de ácido cítrico. Poli(etileno glicol) e poli(álcool vinílico) foram testados como ligantes. O processo de spray drying resultou em microesferas com diâmetros médios de aproximadamente 20 um e esfericidade (razão de comprimentos na horizontal e na vertical) próxima a um, características essenciais para várias aplicações, como a liberação controlada de drogas e cimentos ósseos injetáveis. A adição dos ligantes foi necessária para reduzir a quantidade de partículas soltas e aumentar a fluidez do pó, mas também resultou em uma redução na molhabilidade e na área superficial das microesferas. Os melhores resultados foram obtidos com 3\% de PVA já que as microesferas apresentaram a maior área superficial, molhabilidade e esfericidade. As microesferas preparadas neste estudo podem ser utilizadas como precursoras de cimentos ósseos injetáveis, já que a sua geometria esférica e sua fluidez favorecem a homogeneidade e injetabilidade das pastas sobrepujando as principais dificuldades dos cimentos injetáveis atuais.

Palavras-chave: microesferas, spray drying, $\alpha$-fosfato tricálcico.

\section{INTRODUCTION}

Tricalcium phosphate $\left[\mathrm{TCP}, \mathrm{Ca}_{3}\left(\mathrm{PO}_{4}\right)_{2}\right]$ bioceramics have successfully been employed for bone regeneration for the past 40 years. Their bioactivity, osteoconductivity, and reabsorption depend on the crystalline polymorph they are made of $[1,2]$. There are three known TCP polymorphs: $\beta$-TCP, $\alpha$-TCP and $\alpha^{\prime}$-TCP [2]. $\beta$-TCP is stable at temperatures below $1115 \pm 10^{\circ} \mathrm{C}$. On the other hand, $\alpha$-TCP is formed at $1115 \pm 10^{\circ} \mathrm{C}$ and exists on temperatures as high as $1465 \pm 5{ }^{\circ} \mathrm{C}$. Above this temperature up to the melting

*motisuke@unifesp.br

Dhttps://orcid.org/0000-0001-5369-9722 point $\left(\sim 1756{ }^{\circ} \mathrm{C}\right)$, metastable $\alpha^{\prime}$ phase is formed $[3,4] . \alpha$ and $\beta$ are the only polymorphs with biomedical interest and, despite having the same chemical composition, they present quite different chemical and biological properties influencing in their applicability. $\alpha$-TCP is more soluble than $\beta$ and has higher specific energy and lower density which grants more reactiveness in aqueous systems where it can be hydrolyzed into calcium deficient hydroxyapatite, resulting in a reduction of the degradation rate [4-7]. At $37^{\circ} \mathrm{C}$ the solubility of $\alpha$ and $\beta$ are close ( $\alpha$-TCP presents a solubility of $0.24 \mathrm{mg} . \mathrm{L}^{-1}$, and $\beta$ has $\left.0.15 \mathrm{mg} . \mathrm{L}^{-1}\right)$, however after $\alpha$-TCP dissolution the product formed is one of the most stable calcium orthophosphate, which is the calcium-deficient hydroxyapatite (CDHA) $[2,8]$.

TCP microspheres present a higher rate of in vivo 
resorption when compared to dense blocks $[9,10]$ due to their larger specific surface area, porosity and surface reactivity, increased rate of bone ingrowth, minimized inflammatory responses, higher packing, and good flowability. Therefore, they are suitable for many applications [11-13] such as filling bone defects $[10,14,15]$, formulating injectable pastes and cements [16-19], drugs, genes and cells carriers [20-22], being used for thermal-spray coatings [23], and serving as raw materials for $3 \mathrm{D}$ printed and robocasted bone implants [24, 25]. The shape and size of implantable TCP microspheres should be carefully controlled since it has been shown that they determine the extent of tissue reaction [26] as well as the handling properties of cement pastes and putties (mainly packing and injectability) $[19$, 27]. Moreover, sphericity, i.e. horizontal and vertical length ratio, also determines the necessary flowability of powders used in thermal-spray coating technologies [23] and 3D additive manufacturing [24, 28-30].

Spray drying is one of the preferred methods for manufacturing spherical microparticles [20, 31, 32]. It is a simple method: the liquid droplets are dried while suspended into a drying gas chamber. This liquid feed contains the precursors that transform into a free-flowing dry powder in a continuous process [33]. Solid content, feeding liquid and flow rate can be used to control the size of the obtained microparticles $[20,23,27,31,34]$. The process is lowcost, quite efficient and very reproducible. It can be easily scaled up to nearly any production scale and is extensively used in pharmaceutical, food and ceramic industries [20, $33,35-39]$. Spray drying has already being employed to manufacture hydroxyapatite [11, 31, 40-42], $\beta$-TCP [13] and biphasic calcium phosphate [41, 42] microspheres for several biomedical applications. However, no reports could be found in the preparation of $\alpha$-TCP microspheres by spray drying. This is probably due to the fact that $\alpha$-TCP easily hydrolyzes into CDHA when in contact with water [43], leading to possible clogging of the atomizer nozzle and/or crystalline phase transformation, making necessary the use of organic solvents and increasing the complexity and the costs of the process. Therefore, in this study, $\alpha$-TCP microspheres were manufactured by spray drying from a slurry of synthesized and dry milled $\alpha$-TCP in the presence of hydrolysis inhibitor and binders.

\section{MATERIALS AND METHODS}

Preparation of the $\alpha$-TCP microspheres: $\alpha$-TCP was synthesized by solid-state reaction of a stoichiometric mixture of $\mathrm{Mg}$-free $\mathrm{CaCO}_{3}$ and $\mathrm{CaHPO}_{4}$ at $1300{ }^{\circ} \mathrm{C}$ [44], followed by ball milling during $96 \mathrm{~h}\left(\mathrm{ZrO}_{2}\right.$ balls of 10 and $15 \mathrm{~mm}$ diameter; ball to powder ratio of 10:1 wt/wt). The resulting powder was analyzed by laser diffraction (mod. 1190, Cilas, France). $\alpha$-TCP slurries were prepared by dispersing 50 wt $\%$ of $\alpha$-TCP into an aqueous solution containing $1.0 \mathrm{wt} \%$ of citric acid, 0.1 mol.L-1 ${ }^{-1} \mathrm{NH}_{3}$ and binder concentrations indicated in Table I. Citric acid was used as dissolution inhibitor. Binders employed were poly(vinyl alcohol) (PVA, mol. wt. 10000-20000 g mol-1 ${ }^{-1}$ Optapix PAF 35, Zschimmer Schwarz, Germany) and poly(ethylene glycol) (PEG, mol. wt. 1350-1650 $\mathrm{g} \mathrm{mol}^{-1}$, Synth, Brazil). The $\alpha$-TCP slurries were immediately fed at $80 \mathrm{~mL} \cdot \mathrm{min}^{-1}$ into a spray drier Mobile Minor (GeaNiro, Denmark) with a capacity of $7 \mathrm{~kg}$ water/h and sprayed with outlet air temperature of $115^{\circ} \mathrm{C}$.

Table I - Binders and their concentrations. [Tabela I - Ligantes e suas concentrações.]

\begin{tabular}{cc}
\hline Binder & Concentration $(\mathrm{wt} / \mathrm{vol} \%)$ \\
\hline PEG & 3.0 \\
PVA & $3.0,10.0$ \\
\hline
\end{tabular}

Characterization of $\alpha$-TCP microspheres: crystalline phases were identified by X-ray diffraction (XRD, D8, Bruker, USA, CuK $\alpha$, Ni filter, $20^{\circ}$ to $40^{\circ} 2 \theta, 0.02^{\circ} \cdot \mathrm{s}^{-1}, 45$ $\mathrm{kV}$ and $40 \mathrm{~mA}$ ). JCPDS files employed were 46-0905 for calcium deficient hydroxyapatite and 09-0348 for $\alpha$-TCP. Morphology, mean size and sphericity of the microspheres were studied by scanning electron microscopy (SEM, TM1000, Hitachi, Japan) using the software ImageJ for size and sphericity measurements (approximately 50 individual microspheres were measured in different images). The microspheres sphericities were determined by the measurement of the diameter in the horizontal and vertical direction. The specific surface area (SSA) was measured by $\mathrm{N}_{2}$ adsorption (Monosorb, Quantachrome, USA) applying the BET model. Total pore volume was measured by $\mathrm{Hg}$ intrusion porosimetry (Pore Master, Quantachrome, USA). Granules flowability in terms of Hausner's ratio (HR) was evaluated by [32]:

$$
\mathrm{HR}=\mathrm{V}_{\mathrm{i}} / \mathrm{V}_{\mathrm{f}}
$$

where $V_{i}$ is the apparent volume and $V_{f}$ the final tapped volume of the powder. The apparent volume was determined by slowly filling a recipient with the free-falling powder, which represented the volume of the granules and the intergranular porosity [32, 45]. The final volume was determined by vibrating the recipient until the volume of the powder stopped to decrease. The flowability of the samples was compared with one-way ANOVA with respect to statistical significance $(\mathrm{p}<0.05)$ of the HR values. To evaluate the influence of the spray dying and binders on the powder wettability, the contact angle was measured using a Goniometer (DSA 100, Krüss, Germany) by the sessile drop technique. Powder samples were slightly compacted into $17.3 \mathrm{~mm}$ discs and contact angle was measured by dropping a $10 \mu \mathrm{L}$ drop of deionized water onto sample's surface. The results interpretation was carried out with Drop Shape Analysis 4 software (Krüss, Germany), using YoungLaplace fit as a baseline method. At least three measurements were made in order to guarantee reproducibility. In order to determine the granule strength by apparent yield pressure (Py), a compaction curve was made by compacting $2 \mathrm{~g}$ of each 
sample at a rate of $1 \mathrm{~mm} / \mathrm{min}$ in a cylindrical steel die, using a universal testing machine (1114-H 1262, Instron, UK), with a maximum force of $20 \mathrm{kN}$. The final dimensions of the resulting compact piece were determined; the $\log$ (pressure) $\mathrm{x}$ compactness response (compaction curve) could be backcalculated from the load and displacement curves. Then, as shown in Fig. 1, Py was determined from the intersection of two straight lines that were fitted in the low-pressure and high-pressure legs of the compaction curve [46].

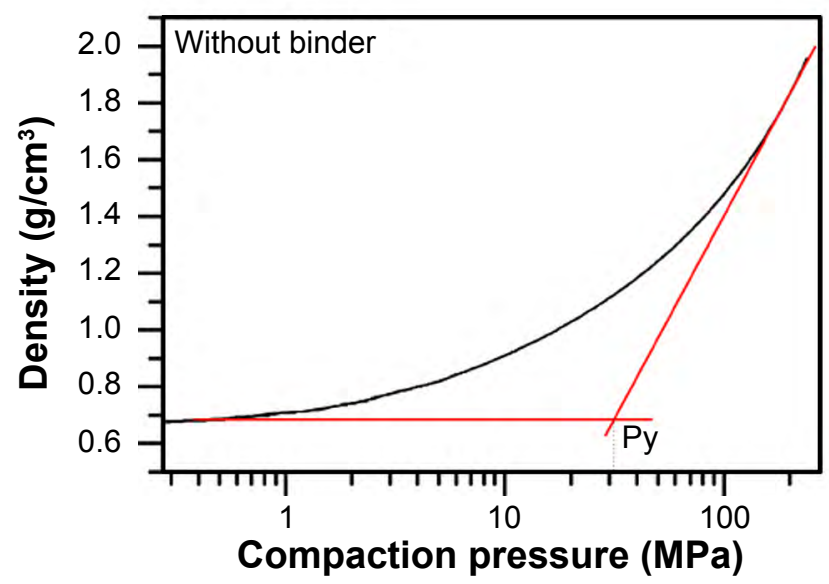

Figure 1: Compaction curve of the microspheres without binders to determine the apparent yield pressure, Py.

[Figura 1: Curva de compactação das microesferas sem ligante para determinação da pressão de escoamento, Py.]

\section{RESULTS AND DISCUSSION}

Fig. 2 shows the XRD patterns of the precursor powder and the as-sprayed microspheres. Citric acid addition was effective in preventing $\alpha$-TCP hydrolysis [47] during the aqueous slurry preparation and atomization as evidenced by the absence of hydroxyapatite diffraction peaks in the XRD patterns of the sprayed microspheres. $\alpha$-TCP (JCPDF 09-0348) was the only crystalline phase detected in the precursor powder and sprayed microspheres. These $\alpha$-TCP microspheres could be applied for the filling of bone defects; the $\alpha$-TCP presents a high solubility, however after the dissolution process the product is a stable calcium orthophosphate. Some researchers have studied the use of $\alpha$-TCP granules; according to [48], after 86 weeks, $95-97 \%$ of $\alpha$-TCP was resorbed, and the remained material was incorporated in the new-formed bone. Kihara et al. [49] studied the degradation of $\alpha$-TCP particles and observed an osteoconductive material, that could be applied in bone regeneration as space maintainers.

The SEM micrographs of sprayed microspheres are displayed in Fig. 3. It was evident that the precursor powder (Fig. 3a) with irregular morphology and a mean particle size of $2.8 \mu \mathrm{m}$ and $90 \mathrm{vol} \%$ with particle sizes in the range of $1.0-7.3 \mu \mathrm{m}$ has changed to spherical granules after the spray drying process. The sprayed particles had a sphericity index close to one, despite the use and nature of the binder (Table II). Nevertheless, the sample without any binder presented a

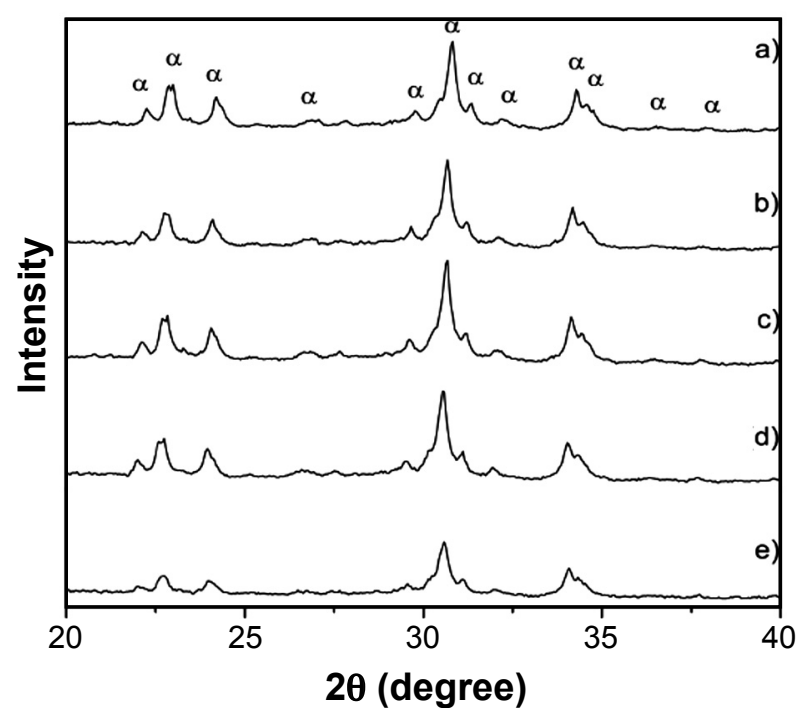

Figure 2: X-ray diffraction patterns of the precursor powder (a), and as-sprayed microspheres without a binder (b), and with $3 \mathrm{wt} \%$ PEG (c), 3 wt $\%$ PVA (d), and 10 wt $\%$ PVA (e). $\alpha: \alpha$-TCP.

[Figura 2: Padrões de difração de raios $X$ do pó precursor (a) e das microesferas sem ligante (b) e com 3\% de PEG (c), 3\% de $P V A(d)$ e $10 \%$ de PVA (e) - \% em massa. $\alpha: \alpha-T C P)$.

large amount of fine precursor powder aggregates coexisting with the microspheres (Fig. 3b). The amount of loose particles of the precursor powder was drastically lowered when binders were added to the slurries. Probably it was due to the low strength of the microspheres and the beginning of their deagglomeration. Binders, in the amounts presented in Table I, were effective in increasing the cohesiveness and the compaction of the sprayed particles and to provide green strength to the sprayed microspheres [50, 51]. The best results were obtained for 3 and $10 \mathrm{wt} \%$ PVA additions which minimized the amount of loose precursor powder and yielded particles with sphericity index of 0.94 and 0.93 , respectively.

The mean diameter, specific surface area and total porosity of the $\alpha$-TCP microspheres are displayed in Table II. Binder addition led to a decrease in all three characteristics: i) specific surface area due to the surface coating; ii) mean diameter caused by the binding action between particles; and iii) total porosity due to the closing of the interparticle porosity by the binder. The lower surface area after binder addition was related to molecular weight and coating efficacy of the binder rather than to mass concentration. As the surface area depends on the coverage of each molecule, the higher the number of binder molecules added, the higher the reduction in the surface area [50]. In fact, as can be seen in Table II, the surface areas of samples with $3 \mathrm{wt} \%$ of PEG and PVA were different, even though these binders were added at the same weight percentage. The surface area of the sample with $3 \mathrm{wt} \%$ of PEG decreased $41 \%$ when compared to sample without additive, whereas the surface area reduction with $3 \mathrm{wt} \%$ of PVA was only $17.6 \%$. This occurred since the molecular weight of PVA was higher than PEG, resulting in a smaller number of PVA molecules 

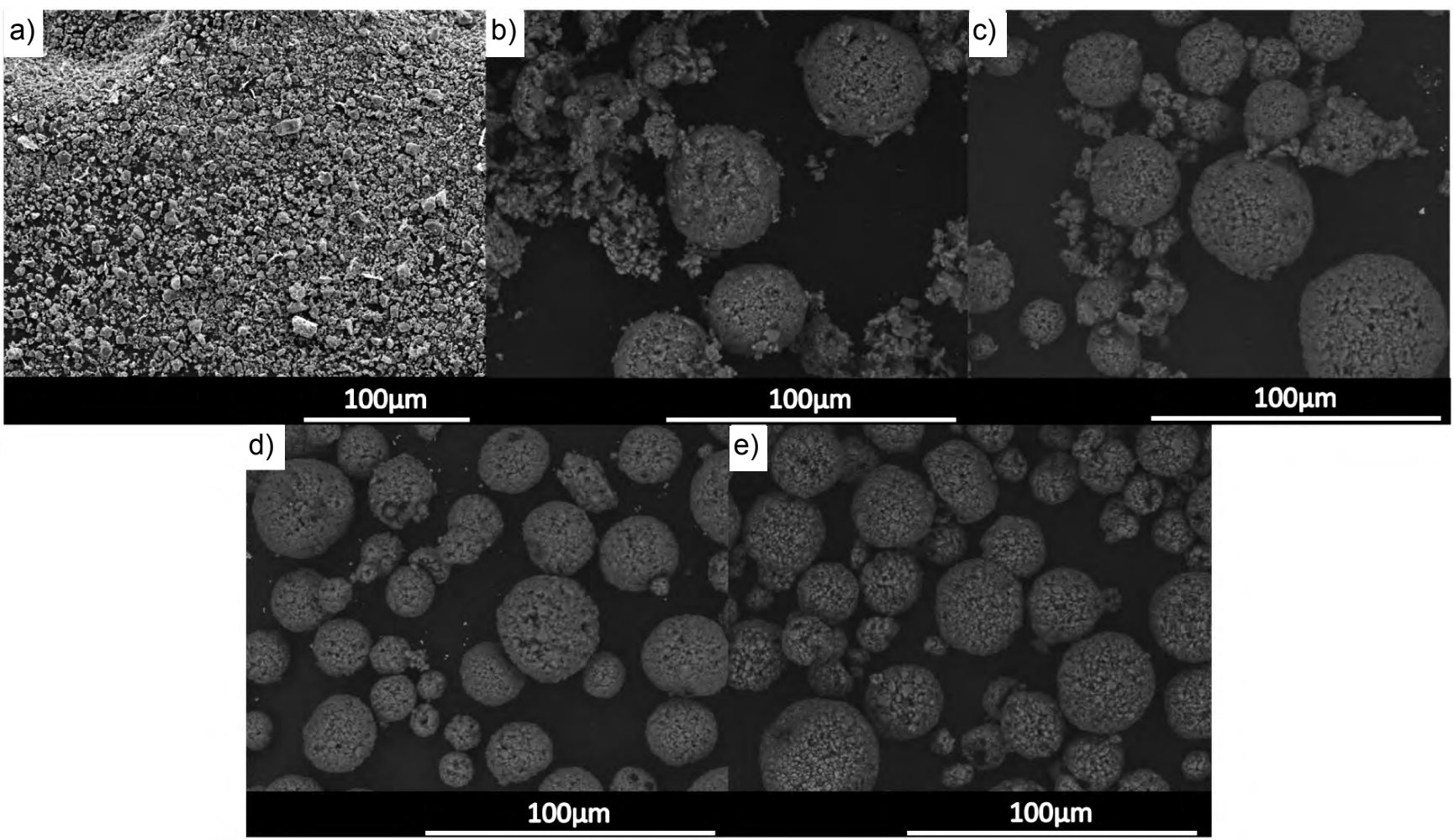

e)

Figure 3: SEM micrographs of the precursor powder (a), and sprayed microspheres without a binder (b), and with 3 wt $\%$ PEG (c), 3 wt $\%$ PVA (d), and $10 \mathrm{wt} \%$ PVA (e).

[Figura 3: Micrografias de MEV do pó precursor (a) e das microesferas sem ligante (b) e com 3\% de PEG (c), 3\% de PVA (d) e 10\% de PVA (e) - \% em massa.]

that was added to the suspension. Therefore, the coating level of the particles was smaller and, consequently, increased the surface. Considering that higher specific surface area should favor microspheres' surface reactivity and interaction with biological media [20], the best binder option for preparing $\alpha$-TCP microspheres should be $3 \mathrm{wt} \%$ of PVA since it presented the highest value of specific surface area.

The Hausner's ratios are presented in Table II. For free-flowing powder, the reference value of Hausner is 1.25 and for poor flowability is higher than 1.5 [52]. Sample without binder presented HR value higher than 1.5 , indicating its poor flowability; however, after binder addition the flowability of the atomized powders was improved. According to [53], powders with Hausner ratios in the range of 1.25 to 1.4 are in the transitional group freeflowing/cohesive and have properties in common with both types, i.e. properties of cohesive strength, internal friction, wall friction, bulk density and permeability [54]. From the one-way ANOVA statistical test of the Hausner's ratio there was no significant difference between the samples with $3 \mathrm{wt} \%$ of PVA and $10 \mathrm{wt} \%$ of PVA ( $>0.05)$. According to [55], the Hausner ratio decreases with the increase in sphericity; thus, this is one physical property which affects the flowability of powders since irregular morphology, i.e. irregular particles (sphericity lower than 1), leads to more surface contacts, an increase in the frictional forces and the particles resist to flow, resulting in a low apparent density $[45,53]$. On the other hand, with spherical form, i.e. particles with sphericity (vertical and horizontal length ratio) closest to one, the frictional forces decrease improving the flowability $[32,56]$. As seen in Figs. $3 \mathrm{~b}$ and $3 \mathrm{c}$, samples without additives and with $3 \mathrm{wt} \%$ of PEG were less spherical when compared with those obtained with the PVA confirming the Hausner's ratio results.

In Table II, it was observed that all samples presented statistically the same sphericity regardless of the use and nature of the binder, proving the efficacy of the process. However, for this measure it was considered only the microspheres that had been formed, i.e., not considering the loose and not granulated powder, and this remaining powder presented irregular form that decreased the flowability, i.e., the higher the amount of microspheres with sphericity closest to one, the higher was the flowability of the powder. According to [53], increasing particle size, the cohesiveness of the powder decreases, resulting in a better flowability; this occurs because the larger particle size diminishes the influence of forces between particles (van der Waals forces). Therefore, the Hausner's ratio decreases with the increase in particle size. Notwithstanding, the results here presented were not consistent with the one presented in [53], since the samples without additives and with 3 wt $\%$ PEG had higher values of mean diameter and Hausner's ratio. This fact could be explained taking into account Figs. $3 b$ and $3 c$, where a large amount of precursor's loose particles was present, which did not 
Table II - Mean diameter (MD), sphericity, specific surface area (SSA), total porosity, granule flowability - Hausner's ratio (HR), and apparent yield pressure (Py) of $\alpha$-TCP microspheres.

[Tabela II - Diâmetro médio (MD), esfericidade, área superficial (SSA), porosidade total, fluidez dos grânulos - índice de Hausner (HR), e pressão de escoamento (Py) das microesferas de $\alpha$-TCP.]

\begin{tabular}{ccccccc}
\hline Sample & $\mathrm{MD}(\mu \mathrm{m})$ & Sphericity & $\mathrm{SSA}\left(\mathrm{m}^{2} \cdot \mathrm{g}^{-1}\right)$ & Total porosity $(\%)$ & $\mathrm{HR}$ & $\mathrm{P}_{\mathrm{v}}(\mathrm{MPa})$ \\
\hline Without binder & $34 \pm 8$ & $0.93 \pm 0.06$ & 1.7 & 50 & $1.79 \pm 0.05$ & 31.6 \\
$3.0 \%$ PEG & $30 \pm 10$ & $0.90 \pm 0.07$ & 1.0 & - & $1.49 \pm 0.06$ & 34.1 \\
$3.0 \%$ PVA & $21 \pm 9$ & $0.94 \pm 0.06$ & 1.4 & 39 & $1.30 \pm 0.03$ & 34.7 \\
$10.0 \%$ PVA & $21 \pm 7$ & $0.93 \pm 0.05$ & 0.7 & 41 & $1.33 \pm 0.01$ & 21.6 \\
\hline
\end{tabular}

exhibit the spherical morphology, and, therefore, hindering the flowability of the powder [55].

The values of apparent yield pressure (Py) determined from the compaction curves are displayed in Table II. The yield pressure was expected to decrease with the addition of $3 \mathrm{wt} \%$ of polymer; notwithstanding, it slightly increased. This may mean that the particles were properly coated with the additive which was acting only as a binder and not as a plasticizer, so reducing the friction between the particles and increasing the green strength of the granules [57]. On the other hand, when $10 \mathrm{wt} \%$ of PVA was added, the yield pressure decreased by almost $40 \%$ due to the plastic behavior of the particles promoted by a thick layer of the polymer, i.e. the distance between particles was increased.

Both the spray drying process and the incorporation of additives influenced on the contact angle, i.e. on the wettability. As observed in Table III, atomization improved wettability (decreased contact angle) while the additives diminished it. Binders' coverage of the particle surface obstructed water penetration and increased the contact angle. This was the reason the sample with $3 \mathrm{wt} \%$ of PVA had contact angle closer to sample without additives $\left(26.8^{\circ}\right.$ and $23.1^{\circ}$, respectively) since, as discussed earlier, PVA had lower molecular weight and produced a smaller reduction on surface area and total porosity. Indeed, by correlating the results of surface area, total porosity and contact angle, it was possible to observe that the sample with $10 \mathrm{wt} \%$ of PVA presented the lowest surface area and the highest contact angle, i.e. the higher the amount of additive, the higher was the coverage of the particle surface hindering water penetration and lowering the wettability. Therefore, one way to control wettability and surface reactivity of granulated powders and, consequently, to control the viscosity of injectable pastes and putties, is by increasing

Table III - Granule wettability - contact angle. [Tabela III - Ângulo de contato dos grânulos.]

\begin{tabular}{cc}
\hline Sample & Contact angle (degree) \\
\hline Precursor powder & $48 \pm 6$ \\
Without binder & $23 \pm 4$ \\
$3.0 \%$ PEG & $31 \pm 5$ \\
$3.0 \%$ PVA & $27 \pm 3$ \\
$10.0 \%$ PVA & $35 \pm 2$ \\
\hline
\end{tabular}

or decreasing the quantity of binders on the slurry that is atomized. If the interest is high wettability and high surface area, the option is to use binders with lower molecular weight and in smaller amounts.

\section{CONCLUSIONS}

Pure phase $\alpha$-TCP microspheres with a mean particle size around $20 \mu \mathrm{m}$ and sphericity index close to one were prepared by spray drying of $50 \mathrm{wt} \%$ aqueous slurries of an $\alpha$-TCP precursor powder. Citric acid was effective in avoiding $\alpha$-TCP hydrolysis during atomization. Comparing the different binders and concentrations tested, best results were obtained when $3.0 \mathrm{wt} \%$ of PVA was employed. The microspheres prepared according to this study can be used to design injectable bone cements for biomedical applications in bone tissue engineering.

\section{ACKNOWLEDGMENTS}

C.O. Reno thanks FAPESP, São Paulo, Brazil, for the scholarships (Process No. 2013/03208-1, 2013/26248-9). Authors would like to thank FAPESP, São Paulo, Brazil for the financial support (Process No 2013/19642-2). R.G. Carrodeguas thanks CNPq, Brazil, for DCR Grant Process No. 351182/2013-6. Authors recognize the financial support from the Ministry of Economy and Competitiveness of Spain provided through projects BIOJER (MAT2013-48426C2-1-R). Authors would like to thank Prof. Anderson de Oliveira Lobo, PhD from Universidade do Vale do Paraíba (UNIVAP) for permitting contact angle analysis.

\section{REFERENCES}

[1] S.V. Dorozhkin, Biomaterials 31 (2010) 1465.

[2] R.G. Carrodeguas, S. De Aza, Acta Biomater. 7 (2011) 3536.

[3] R.G. Carrodeguas, A.H. De Aza, X. Turrillas, P. Pena, S. De Aza, J. Am. Ceram. Soc. 91 (2008) 1281.

[4] S.V. Dorozhkin, Bioceram. Dev. Appl. 4 (2014) 081.

[5] S.V. Dorozhkin, Materials 2 (2009) 221.

[6] J. Czechowska, A. Zima, J. Lis, Ś. Anna, Ceram. Int. 40 (2013) 5523.

[7] G. Mestres, C. Le Van, M.-P. Ginebra, Acta Biomater. 8 (2012) 1169. 
[8] L. Wang, G.H. Nancollas, Chem. Rev. 108 (2008) 4628. [9] R.A. Perez, S. Del Valle, G. Altankov, M.-P. Ginebra, J. Biomed. Mater. Res. B. Appl. Biomater. 97 (2011) 156.

[10] B. Li, Z. Liu, J. Yang, Z. Yi, W. Xiao, X. Liu, X. Yang, W. Xu, X. Liao, Mater. Sci. Eng. C 70 (2017) 1200.

[11] R. Sun, Y. Lu, K. Chen, Mater. Sci. Eng. C 29 (2009) 1088.

[12] M. Ginebra, M. Espanol, E. Montufar, Acta Biomater. 6 (2010) 2863.

[13] D.-H. Kim, S.S. Park, J.D. Lee, H.-C. Park, S.-Y. Yoon, Powder Technol. 257 (2014) 74.

[14] Y.Gonda, K. Ioku, Y. Shibata, T. Okuda, G. Kawachi, M. Kamitakahara, H. Murayama, K. Hideshima, S. Kamihira, I. Yonezawa, H. Kurosawa, T. Ikeda, Biomaterials 30 (2009) 4390.

[15] K.A. Shariff, K. Tsuru, K. Ishikawa, Mater. Sci. Eng. C 75 (2017) 1411.

[16] M. Bohner, G. Baroud, Biomaterials 26 (2005) 1553.

[17] K. Ishikawa, Key Eng. Mater. 240-242 (2003) 369373.

[18] K. Ishikawa, A. Takeuchi, Y. Suzuki, K. Koyano, J. Ceram. Soc. Japan 116 (2008) 63.

[19] C.O. Renó, C.A.C. Zavaglia, M. Motisuke, in Ref. Modul. Mater. Sci. Mater. Eng. (2017), doi:10.1016/B9780-12-803581-8.09387-5.

[20] C. Santos, M.A. Martins, R.-P. Franke, M.M. Almeida, M.E.V. Costa, Ceram. Int. 35 (2009) 1587.

[21] V.S. Komlev, S.M. Barinov, E.V. Koplik, Biomaterials 23 (2002) 3449.

[22] J. Malda, C.G. Frondoza, Trends Biotechnol. 24 (2006) 299.

[23] L. Pawlowski, The science and engineering of thermal spray coatings, $2^{\text {nd }}$ ed., John Wiley Sons (2008).

[24] C. Bergmann, M. Lindner, W. Zhang, K. Koczur, A. Kirsten, R. Telle, H. Fischer, J. Eur. Ceram. Soc. 30 (2010) 2563.

[25] Y. Ben, L. Zhang, S. Wei, T. Zhou, Z. Li, H. Yang, Y. Wang, F.A. Selim, C. Wong, H. Chen, J. Alloys Compd. 721 (2017) 312.

[26] S. Ghanaati, M. Barbeck, C. Orth, I. Willershausen, B.W. Thimm, C. Hoffmann, A. Rasic, R.A. Sader, R.E. Unger, F. Peters, C.J. Kirkpatrick, Acta Biomater. 6 (2010) 4476.

[27] M. Bohner, S. Tadier, N. van Garderen, A. de Gasparo, N. Döbelin, G. Baroud, Biomatter 3 (2013) 1.

[28] A. Butscher, M. Bohner, S. Hofmann, L. Gauckler, R. Müller, Acta Biomater. 7 (2011) 907.

[29] U. Klammert, U. Gbureck, E. Vorndran, J. Rödiger, P. Meyer-Marcotty, A.C. Kübler, J. Cranio Maxill. Surg. 38 (2010) 565 .

[30] A. Butscher, M. Bohner, C. Roth, A. Ernstberger, R. Heuberger, N. Doebelin, P.R. von Rohr, R. Müller, Acta Biomater. 8 (2012) 373.
[31] A. Wang, Y. Lu, R. Zhu, S. Li, X. Ma, Powder Technol 191 (2009) 1.

[32] P. Ramavath, M. Swathi, M. Buchi Suresh, R. Johnson, Adv. Powder Technol. 24 (2013) 667.

[33] H. Schwartzbach, Pharm. Technol. Eur. 22 (2010) 5.

[34] K. Lin, D. Zhai, N. Zhang, N. Kawazoe, G. Chen, J. Chang, Ceram. Int. 40 (2014) 3287.

[35] A. Sosnik, K.P. Seremeta, Adv. Colloid Interface Sci. 223 (2015) 40 .

[36] S.P. Tan, T.C. Kha, S.E. Parks, C.E. Stathopoulos, P.D. Roach, Powder Technol. 281 (2015) 65.

[37] S. Arslan, M. Erbas, I. Tontul, A. Topuz, LWT Food Sci. Technol. 63 (2015) 685.

[38] A. Bianchini, M. Pellegrini, C. Saccani, Powder Technol. 283 (2015) 113.

[39] V. Landillon, D. Cassan, M.-H. Morel, B. Cuq, J. Food Eng. 86 (2008) 178.

[40] S.W. Kweh, K. Khor, P. Cheang, J. Mater. Process. Technol. 89-90 (1999) 373.

[41] X.D. Zhu, H.J. Zhang, H.S. Fan, W. Li, X.D. Zhang, Acta Biomater. 6 (2010) 1536.

[42] J. Wang, H. Zhang, X. Zhu, H. Fan, Y. Fan, X. Zhang, J. Biomed. Mater. Res. B Appl. Biomater. 101 (2013) 1069.

[43] M.-P. Ginebra, C. Canal, M. Espanol, D. Pastorino, E.B. Montufar, Adv. Drug Deliv. Rev. 64 (2012) 1090.

[44] M. Motisuke, R.G. Carrodeguas, C.A.D.C. Zavaglia, Key Eng. Mater. 363 (2008) 199.

[45] J.L.A. Albaro, A.B. Fuentes, J.E.E. Navarro, F.N. Medall, Bol. Soc. Esp. Ceram. V. 26 (1987) 31.

[46] J.L. Amorós, V. Cantavella, J.C. Jarque, C. Felíu, J. Eur. Ceram. Soc. 28 (2008) 2823.

[47] S. Sarda, E. Fernández, M. Nilsson, M. Balcells, J.A. Planell, J. Biomed. Mater. Res. 61 (2002) 653.

[48] J. Wiltfang, H.A. Merten, K.A. Schlegel, S. SchultzeMosgau, F.R. Kloss, S. Rupprecht, P. Kessler, J. Biomed. Mater. Res. 63 (2002) 115.

[49] H. Kihara, S. Makoto, Y. Yamashita, S. Kasugai, J. Biomed. Mater. Res. B Appl. Biomater. 79 (2005) 284.

[50] S. Lukasiewicz, J. Am. Ceram. Soc. 72 (1989) 617.

[51] F.E. Bastan, E. Demiralp, Y.Y. Özbek, F. Üstel, Mater. Tehnol. 47 (2013) 303.

[52] E. Sánchez, A. Moreno, M. Vicent, M.D. Salvador, V. Bonache, E. Klyatskina, I. Santacruz, R. Moreno, Surf. Coat. Technol. 205 (2010) 987.

[53] E.C. Abdullah, D. Geldart, Powder Technol. 102 (1999) 151.

[54] J. Prescott, R. Barnum, Pharm. Technol. 24 (2000) 60.

[55] R.P. Zou, A.B. Yu, Powder Technol. 88 (1996) 71.

[56] M. Vicent, E. Sánchez, T. Molina, M.I. Nieto, R. Moreno, J. Eur. Ceram. Soc. 32 (2012) 1019.

[57] S. Balasubramanian, J. Am. Ceram. Soc. 85 (2002) 134. (Rec. 17/04/2019, Rev. 15/05/2019, Ac. 21/05/2019) 